\title{
PENGARUH MODEL PEMBELAJARAN TPS \\ DENGAN MEDIA ICM TERHADAP HASIL BELAJAR KIMIA SISWA
}

\author{
Rabiatul Adawiyah ${ }^{1)}$, Zona Octarya ${ }^{2)}$ \\ ${ }^{1)}$ Mahasiswa S1 Program Studi Pendidikan Kimia, Fakultas Tarbiyah dan Keguruan, Universitas Islam \\ Negeri Sultan Syarif Kasim Riau \\ E-mail : rabiatuladawiyah995@gmail.com \\ ${ }^{2)}$ Dosen Program Studi Pendidikan Kimia, Fakultas Tarbiyah dan Keguruan, \\ Universitas Islam Negeri Sultan Syarif Kasim Riau \\ E-mail : souvenirzonc@yahoo.co.id
}

\begin{abstract}
This research aimed at knowing the effect of using TPS learning model with ICM media toward student chemistry learning achievement on Hydrocarbon lesson at the tenth grade of State Senior High School 2 Rumbiojaya. It was instigated by the low of student chemistry learning achievement on Hydrocarbon lesson at the tenth grade of State Senior High School 2 Rumbiojaya. It was a Quasi-experiment with pretest and posttest design. Two classes of the tenth-grade students owning the same homogeneity level were the samples, the tenth grade of classes 2 was as the experimental group and class 3 was as the control group, and Purposive sampling technique was used. Observation, homogeneity test as the preliminary data test, pretest and posttest as the final data test, and documentation were the techniques of collecting the data. t test used to analyze the final data showed that $t_{\text {observed }}$ was 2.038 and $t_{\text {table }}$ was 2.00 at $5 \%$ significant level. It meant that $t_{\text {observed }}$ was higher than $t_{\text {table, }} H_{0}$ was rejected, and $H_{a}$ was accepted. It revealed that there was an effect of using TPS learning model with ICM media toward student learning achievement on Hydrocarbon lesson and the coefficient of effect was $8.6 \%$.
\end{abstract}

Keywords : Think Pair Share, Index Card Match, Learning Achievement, Hydrocarbon.

\section{PENDAhULUAN}

Salah satu tujuan nasional bangsa Indonesia adalah untuk mencerdaskan kehidupan bangsa. Untuk mencapai tujuan tersebut dilakukan melalui pendidikan. Pendidikan merupakan upaya yang dapat mempercepat pengembangan potensi manusia untuk mampu mengemban tugas yang dibebankan padanya, karena hanya manusia yang dapat dididik dan mendidik. Pendidikan dapat mempengaruhi perkembangan fisik, mental emosional, moral, serta keimanan dan ketakwaan manusia [1]. Berdasarkan pengertian pendidikan tersebut maka pendidikan haruslah ditempuh oleh setiap manusia karena manusia sejak lahir telah diberikan akal untuk berpikir, dimana melalui pendidikan setiap manusia mengalami pembelajaran yang akan berguna untuk kehidupannya.
Pembelajaran merupakan proses interaksi siswa dengan guru dan sumber belajar di suatu lingkungan belajar [2]. Dengan kata lain, pembelajaran adalah proses untuk membantu siswa agar dapat belajar dengan baik. Dimana belajar adalah suatu proses usaha yang dilakukan seseorang untuk memperoleh suatu perubahan tingkah laku yang baru secara keseluruhan, sebagai hasil pengalamannya sendiri dalam interaksi dengan lingkungannya [3]. Perubahan tingkah laku ini seperti yang bersifat afektif, kognitif, psikomotor. Sebagaimana firman Allah dalam QS. As-Syura ayat 52: 
Artinya: Dan demikianlah kami wahyukan kepadamu wahyu (Al-Quran) dengan perintah kami. Sebelumnya kamu tidaklah mengetahui apakah Al kitab (Al-Quran) dan tidak pula mengetahui apakah iman itu, tetapi kami menjadikan Al Quran itu cahaya, yang kami tunjuki dengan dia siapa yang kami kehendaki di antara hamba-hamba kami dan sesungguhnya kamu benar-benar memberi petunjuk kepada jalan yang lurus [4].

Dan hadis dari Nabi Muhammad SAW:

Artinya: “Sesungguhnya orang mu'min yang paling dicintai oleh Allah ialah orang yang senantiasa tegak taat kepada-Nya dan memberikan nasihat kepada hamba-Nya, sempurna akal pikirannya, serta mengamalkan ajaran-Nya selama hayatnya, maka beruntung dan memperoleh kemenangan ia" [5].

Berdasarkan ayat dan hadis di atas dapat diambil kesimpulan bahwa Allah SWT telah memerintahkan kepada manusia untuk terus belajar melalui kitab suci yakni AlQuran yang merupakan petunjuk untuk jalan yang lurus, dan memerintahkan untuk manusia saling memberi petunjuk, nasehat, manfaat dari ilmu yang dimiliki.

Salah satu ilmu pengetahuan yang ada di SMA adalah kimia. Kimia merupakan cabang dari ilmu pengetahuan alam, yang berkenaan dengan kajian-kajian tentang struktur dan komposisi materi, perubahan yang dapat dialami materi. Ilmu kimia ini sangat diperlukan dalam kehidupan seharihari karena sangat berkaitan dengan kehidupan manusia. Namun tidak sedikit orang yang yang menganggap kimia sebagai ilmu yang kurang menarik. Disebabkan kimia erat hubungannya dengan ide-ide atau konsep-konsep abstrak, sehingga belajar kimia merupakan kegiatan mental yang membutuhkan penalaran tinggi [6]. Dimana salah satu materi kimia yang diajarkan di kelas X semester genap adalah pokok bahasan Hidrokarbon. Materi Hidrokarbon bersifat pemahaman konsep sebagai dasar dalam mempelajari materi selanjutnya.

Berdasarkan hasil wawancara dengan Guru Mata Pelajaran Kimia di SMA Negeri 2 Rumbiojaya diperoleh informasi bahwa siswa mengalami kesulitan dalam mempelajari materi Hidrokarbon. Dimana siswa sering dibingungkan terhadap konsep dalam penggolongan hidrokarbon, penamaan, pembuataan struktur serta reaksi yang terjadi pada hidrokarbon. Hal ini dibuktikan dengan adanya siswa yang mendapatkan nilai dibawah KKM pada materi Hidrokarbon. Selain itu proses pembelajaran masih terfokus pada guru, adanya siswa yang malu untuk bertanya dan berpendapat, kurangnya kesiapan siswa dalam mengikuti pelajaran sehingga menyebabkan rendahnya hasil belajar siswa.

Berdasarkan permasalahan tersebut diharapkan dengan menerapkan salah satu model pembelajaran kooperatif yaitu model pembelajaran Think Pair Share (TPS) dengan media Index Card Match (ICM) siswa lebih dapat memahami materi hidrokarbon. Sebagaimana firman Allah dalam QS. AnNahl ayat 125:

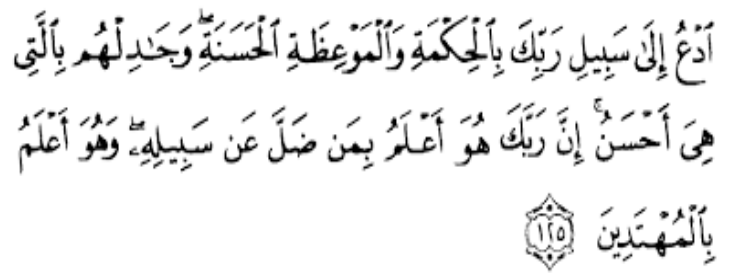

Artinya: Serulah (manusia) kepada jalan Tuhan-mu dengan hikmah dan pelajaran yang baik dan bantahlah mereka dengan cara yang baik. Sesungguhnya Tuhanmu Dialah yang lebih mengetahui tentang siapa yang tersesat dari jalan-Nya dan Dialah yang lebih mengetahui orang-orang yang mendapat petunjuk [7].

Ayat tersebut menjelaskan bagaimana cara untuk menyampaikan ilmu atau nasehat dengan lembut dan membantah suatu masalah dengan cara baik serta bagaimana menyampaikan suatu ilmu dengan model atau cara paling tepat, cocok dan sesuai dengan 
karakter orang yang akan menerimanya sehingga tujuan pembelajaran dapat tercapai.

Model pembelajaran Think Pair Share sebelumnya telah dilakukan oleh peneliti Surayya tahun 2014 dari penelitian yang dilakukannya terdapat pengaruh dari penggunaan model pembelajaran Think Pair Share terhadap hasil belajar yaitu rata-rata hasil belajar pada model Think Pair Share sebesar 69,27 dibandingkan dengan kelas dengan yang memakai model pembelajaran konvensional sebesar 61,45 [8].

Model pembelajaran kooperatif tipe Think Pair Share merupakan model pembelajaran yang dikembangkan oleh Frank Lyman dari Univeristas Maryland. Pada saat guru mempresentasikan sebuah pelajaran di kelas, siswa duduk berpasangan didalam tim mereka. Tiga tahapan dalam model pembelajaran ini adalah: (1) Think. Guru mengajukan pertanyaan kepada siswa, dan pada tahap ini siswa diminta untuk memikirkan sendiri atas jawaban pertanyaan itu, (2) Pair. Setelah siswa diminta memikirkan sendiri atas jawaban dari pertanyaan yang diberikan oleh guru, pada tahap ini siswa berpasangan dengan pasangan diskusinya untuk mencapai konsesus atas jawaban tersebut, (3) Share. Setelah berpasangan dalam tahap ini guru meminta siswa untuk share (berbagi) jawaban yang mereka sepakati itu kepada semua siswa di kelas [9].

Penerapan model pembelajaran Think Pair Share perlu adanya penunjang untuk mengoptimalkan proses pembelajaran, salah satunya dengan menggunakan media Index Card Match. Media Index Card Match sebelumnya pernah dilakukan oleh Dian Anita Nugraha tahun 2013 dari penelitian yang dilakukannya terdapat pengaruh hasil belajar siswa dari penggunaan media Index Card Match pada kelas eksperimen yaitu sebesar 55,1 sedangkan pada kelas kontrol hanya $50,0[10]$.

Media Index Card Match mengandung sisi yang menarik, menyenangkan, dan mudah dilakukan. Maka dengan diterapkan metode Think Pair Share yang dilengkapi media Index Card Match, yang merupakan suatu media pendidikan dalam proses pembelajaran. Media pendidikan dengan bentuk kartu berpasangan ini akan menjadikan kelas jauh dari ketegangan sehingga akan memudahkan siswa menerima pelajaran dan diharapkan siswa lebih mudah mempelajari dan memahami isi materi tersebut dan akan mampu meningkatkan daya keaktifan siswa dalam belajar serta dapat mengembangkan pengetahuan, sikap dan keterampilan sehingga dapat berkembang secara mandiri. Index Card Match adalah strategi yang cukup menyenangkan yang digunakan untuk mengulang materi yang telah diberikan sebelumnya. Namun demikian, materi baru pun tetap bisa diajarkan dengan strategi ini dengan catatan, peserta didik diberi tugas mempelajari topik yang akan diajarkan terlebih dahulu, sehingga ketika masuk kelas mereka sudah memiliki bekal pengetahuan [11].

Dari latar belakang masalah yang dijelaskan di atas, maka peneliti tertarik untuk melakukan penelitian yang berjudul "Pengaruh Model Think Pair Share dengan Media Index Card Match terhadap Hasil Belajar Kimia Siswa pada Materi Hidrokarbon Kelas X di Sekolah Menengah Atas Negeri 2 Rumbiojaya"

\section{METODE PENELITIAN}

Penelitian ini dilakukan di SMA Negeri 2 Rumbiojaya pada bulan April-Mei 2017. Populasi dalam penelitian ini adalah seluruh siswa/siswi kelas $\mathrm{X}$ semester genap SMA Negeri 2 Rumbiojaya tahun ajaran 2016/2017 yaitu kelas X1, X2, X3, dan X4 . Teknik pengambilan sampel menggunakan teknik Purposive Sampling. Sampel dalam penelitian ini adalah kelas yang siswasiswinya homogen yaitu kelas X2 sebagai kelas eksperimen diberi perlakuan model Think Pair Share dengan media Index Card Match dan kelas X3 sebagai kelas kontrol dengan model konvensional (ceramah) yang didapat dari uji homogenitas.

Teknik pengumpulan data menggunakan: (1) tes yaitu uji homogenitas, pretest dan posstest untuk mengetahui kemampuan kognitif siswa sebelum dan 
sesudah diberi perlakuan; (2) observasi untuk mengamati proses pembelajaran berlangsung termasuk sistem dan metode pembelajaran yang digunakan yang berkaitan dengan hasil belajar kognitif siswa; (3) dokumentasi untuk memperkuat data yang diperoleh di sekolah.

Metode penelitian yang digunakan adalah metode quasi eksperiment dengan desain penelitian yang tercantum pada tabel berikut:

Tabel 1. Rancangan Penelitian Pretest dan Posttest

\begin{tabular}{cccc}
\hline Kelompok & Pretest & Perlakuan & Posttest \\
\hline Eksperimen & $\mathrm{T}_{1}$ & $\mathrm{X}$ & $\mathrm{T}_{2}$ \\
Kontrol & $\mathrm{T}_{1}$ & - & $\mathrm{T}_{2}$ \\
\hline
\end{tabular}

Keterangan :

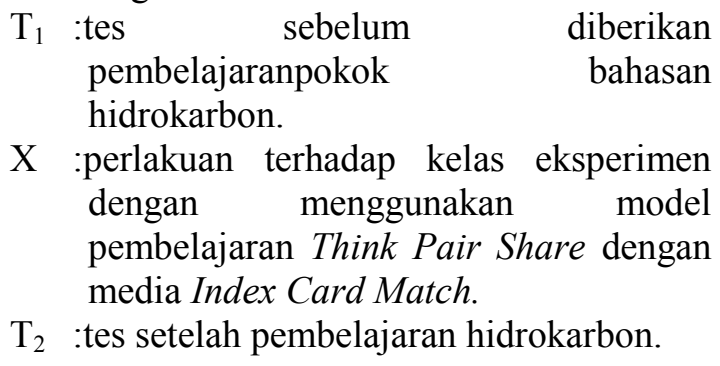

Teknik analisis data terdiri dari teknik (1) analisis butir soal yaitu validitas soal dengan rumus korelasi point biserial; reliabilitas tes dengan rumus Kuder Ricardson (KR-20); daya pembeda soal; dan tingkat kesukaran soal; (2) analisis data penelitian yaitu analisis data awal (uji homogenitas) dengan uji Bartlet; uji normalitas dengan rumus chi kuadrat; dan analisis data akhir (uji hipotesis) dengan uji t.

\section{HASIL DAN PEMBAHASAN}

Pada awal penelitian ini dilakukan uji homogenitas untuk mengetahui populasi yang akan digunakan memiliki kemampuan homogen. Uji homogenitas dilakukan dengan cara memberikan tes kepada siswa yang akan menjadi subjek penelitian dalam bentuk soal pilihan ganda sebanyak 20 butir item soal dan materi yang digunakan adalah materi redoks.

Setelah melakukan uji homogenitas, hasil tes tersebut kemudian dianalisis dengan menggunakan uji Bartlet untuk melihat tingkat kehomogenan dari keempat kelas yang diuji. Jika nilai $\boldsymbol{x}^{2}{ }_{\text {hitung }}<\boldsymbol{x}^{2}$ tabel maka dianggap varians-varians tersebut homogen. Nilai $\boldsymbol{x}{ }^{2}$ hitung diperoleh sebesar 1,176 sedangkan $\boldsymbol{x}_{\text {tabel }}^{2}$ sebesar 7,815. Nilai $\boldsymbol{x}^{2}$ hitung $<\boldsymbol{x}_{\text {tabel }}^{2}$ sehingga dapat dianggap kelas X1, $\mathrm{X} 2$, X3 dan $\mathrm{X} 4$ mempunyai kemampuan yang homogen.

Setelah data didapatkan homogen, selanjutnya dilakukan penentuan sampel untuk penelitian. Pengambilan sampel dapat menggunakan teknik Purposive Sampling dan dipilih kelas X2 sebagai kelas eksperimen diterapkan model pembelajaran Think Pair Share dengan media Index Card Match sedangkan X3 sebagai kelas kontrol yang menggunakan metode konvensional. Untuk soal-soal tes yang digunakan setelah di analisis menggunakan validitas isi dan empiris, reliabilitas, tingkat kesukaran dan daya pembeda soal diperoleh 20 soal yang akan digunakan untuk pretest dan posttest.

Berdasarkan hasil analisis uji coba soal yang telah dilakukan, diperoleh bahwa untuk validitas isi dinyatakan $100 \%$ valid, sedangkan validitas empiris diperoleh 7 soal tidak valid dan 23 soal valid. Uji reliabilitas dilakukan dengan menggunakan rumus KR20 diperoleh reliabilitas soal sebesar 0,851 dengan kriteria tinggi, sehingga soal memiliki keajegan yang tinggi.Tingkat kesukaran soal diperoleh 30\% soal kategori mudah yang berjumlah 6 butir soal, $50 \%$ soal kategori sedang yang berjumlah 10 butir soal dan $20 \%$ soal kategori sukar yang berjumlah 4 butir soal. Dengan demikian maka soal yang peneliti gunakan sebagai instrumen dalam penelitian ini adalah soal dengan kualitas yang baik dengan memakai pola perbandingan soal mudah-sedang-sukar dengan 3-5-2. Daya pembeda soal diperoleh $13,3 \%$ dengan kriteria daya pembeda jelek yang berjumlah 4 soal, 50\% dengan kriteria daya pembeda cukup yang berjumlah 15 soal, $36,7 \%$ dengan kriteria baik yang berjumlah 11 soal. Soal yang dijadikan instrumen dalam penelitian ini berjumlah 20 soal pilihan ganda dengan kriteria daya pembeda cukup 55\% 
dan baik $45 \%$ sebagai soal pretest dan posttest.

Kelas eksperimen memiliki nilai ratarata pretest sebesar 30 dan rata-rata nilai pretest kelas kontrol sebesar 31,25 yang sama-sama terletak dalam kriteria gagal. Nilai pretest ini merupakan nilai rata-rata ketika siswa belum memasuki materi hidrokarbon. Sebagian siswa masih belum banyak mengetahui tentang materi hidrokarbon. Siswa masih bingung karena belum mempelajari materi yang diberikan, mereka mengisi jawaban hanya sebatas pengetahuan yang mereka ketahui. Hasil yang rendah ini menunjukkan bahwa kelas eksperimen dan kelas kontrol sama-sama belum menguasai materi hidrokarbon.

Setelah diterapkan model Think Pair Share dengan media Index Card Match pada kelas eksperimen dan metode konvensional pada kelas kontrol, maka dilakukan posttest. Nilai posttest masing-masing kelas mengalami peningkatan dari pretest karena siswa sudah mempelajari materi tersebut.

\begin{tabular}{cccc}
\hline Kelas & LKS I & LKS II & LKS III \\
\hline Eksperimen & $\mathbf{9 0 , 7 2 7}$ & $\mathbf{9 1 , 1 8 2}$ & $\mathbf{8 5}$ \\
& & & \\
Kontrol & $\mathbf{8 1}$ & $\mathbf{7 0 , 0 8 3}$ & $\mathbf{7 8 , 7 5}$ \\
\hline
\end{tabular}

Kelas eksperimen memiliki nilai rata-rata posttest 81,1. Nilai rata-rata posttest kelas kontrol 77,5. Kelas eksperimen memiliki nilai rata-rata yang lebih tinggi daripada kelas kontrol. Dan untuk soal posttest yang diberikan adalah sama untuk kelas eksperimen dan kelas kontrol yaitu 20 soal pilihan ganda materi hidrokarbon.

Tabel 2. Perbandingan Nilai Pretest Dan Posttest Kelas Kontrol Dan Eksperimen

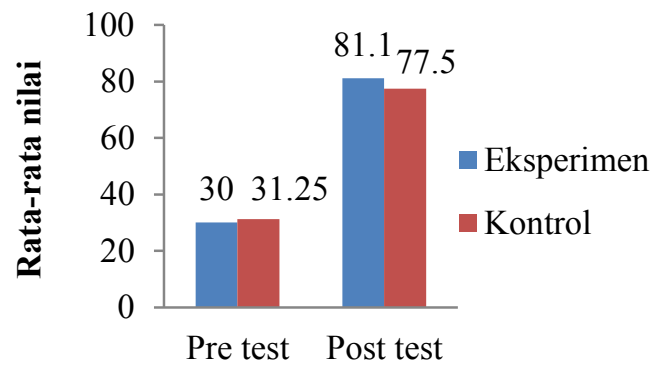

Perbandingan nilai pretest dan posttest kelas eksperimen dan kontrol dapat dilihat pada gambar berikut:

Gambar 1. Perbandingan Rata-Rata Nilai Pretest dan Posttest Kelas Ekperimen dan Kontrol

Nilai rata-rata posttest kelas eksperimen setelah dilakukan penerapan model Think Pair Share dengan media Index Card Match menunjukkan hasil yang lebih baik terhadap hasil belajar siswa dibandingkan dengan kelas kontrol, hal ini dikarenakan siswa telah mengetahui tentang materi hidrokarbon melalui proses pembelajaran yang dilakukan.

Hasil nilai LKS juga menunjukkan bahwa model pembelajaran Think Pair Share dengan media Index Card Match mampu membantu pemahaman siswa terhadap materi pelajaran. Hal ini juga dapat dilihat dari nilai LKS kelas eksperimen dan kelas kontrol di bawah ini:

Tabel 3. Perbandingan Rata-rata Nilai LKS Kelas Eksperimen dan Kelas Kontrol

Perbandingan rata-rata nilai LKS kelas eksperimen dan kontrol dapat dilihat pada gambar berikut:

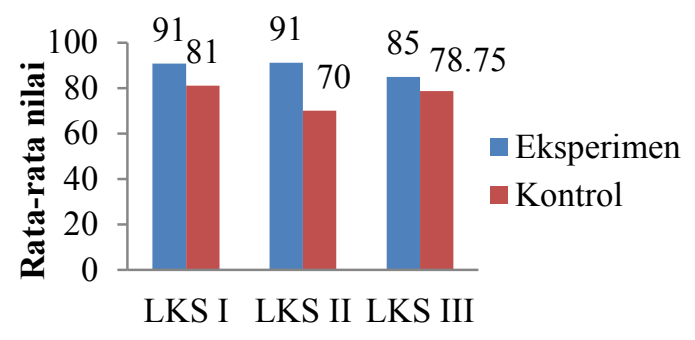

Gambar 2. Perbandingan Rata-rata Nilai LKS Kelas Eksperimen dan

\begin{tabular}{ccc}
\hline Kelas & Pretest & Posttest \\
\hline Eksperimen & 30 & 81,1 \\
Kontrol & 31,25 & 77,5 \\
\hline
\end{tabular}

Kelas Kontrol 
Pembelajaran pada kelas eksperimen yakni menerapkan model pembelajaran Think Pair Share dengan media Index Card Match. Model Think Pair Share dilakukan secara berkelompok yakni satu kelompok terdiri dari dua orang yang memiliki kemampuan heterogen yang membuat rasa tanggung jawab pada setiap individu dikelompok masing-masing. Hal ini sesuai dengan penelitian Muthiah Zuhara dan Utiya Azizah yang menyatakan bahwa dengan jumlah anggota kelompok yang relatif kecil tersebut, rasa tanggung jawab antara keduanya akan lebih muncul ketika mereka ditugaskan untuk menyelesaikan tugas yang diberikan oleh guru [12].

Materi yang diajarkan pada penelitian ini adalah materi hidrokarbon. Materi hidrokarbon merupakan salah satu materi kimia yang membutuhkan pemahaman konsep. Dimana materi ini tergolong rumit karena materi hidrokarbon tidak hanya berisi teori-teori saja tetapi juga mencakup aturan mengenai penamaan, pembuatan sturuktur serta reaksi. Penggunaan model pembelajaran Think Pair Share dengan media Index Card Match dianggap sesuai, dikarenakan karakteristik dari materi hidrokarbon merupakan pemahaman konsep. Dimana model pembelajaran Think Pair Share digunakan untuk materi pelajaran yang bersifat konsep. Hal ini sesuai menurut Ibrahim yang mengatakan bahwa, model pembelajaran Think Pair Share merupakan salah satu model pembelajaran yang unggul dalam membantu siswa memahami konsep yang sulit dan juga dapat menumbuhkan kerjasama antar siswa dengan siswa lain [13]. Model pembelajaran Think Pair Share dilengkapi dengan media Index Card Match. Media Index Card Match. Merupakan media pembelajaran berupa kartu berpasangan yang sederhana dan menyenangkan serta dapat membantu siswa dalam memahami materi hidrokarbon.

Model pembelajaran Think Pair Share terdiri dari tiga tahap, yaitu tahap Thinking (berpikir), Pairing (berpasangan), dan Sharing (berbagi). Dimana guru terlebih dahulu menyampaikan tujuan pembelajaran dan materi. Kemudian siswa diberi pertanyaan oleh guru berupa lembar kerja siswa (LKS). Lembar kerja siswa (LKS) berisikan soal-soal latihan yang berkaitan dengan materi yang dipelajari, diharapkan dengan penggunaan LKS mampu membantu siswa agar dapat memahami materi hidrokarbon. Hal ini sesuai dengan pengertian LKS dalam buku Trianto yang mengatakan bahwa, lembar kerja siswa adalah panduan siswa yang digunakan untuk melakukan kegiatan penyelidikan atau pemecahan masalah. Lembar kerja siswa dapat berupa panduan untuk latihan pengembangan semua aspek kognitif dan untuk memaksimalkan pemahaman dalam upaya pembentukan kemampuan dasar sesuai indikator pencapaian hasil belajar yang harus ditempuh [14].

Pengerjaan soal LKS pada tahap pertama yakni Thinking. Siswa diberi kesempatan untuk memikirkan dan mengerjakan soal secara individu serta dibimbing untuk membangun pengetahuannya sendiri dalam menjawab soal LKS yang diberikan oleh guru, diharapkan dengan siswa membangun pengetahuannya secara individu akan mempermudah pemahaman siswa terhadap materi serta membuat siswa agar dapat membiasakan berpikir dan menganalisis untuk menyelesaikan masalah yakni LKS. Hal ini sesuai dengan Istarani yang mengatakan bahwa, salah satu manfaat model Think Pair Share adalah melatih berfikir siswa secara baik dan dapat membantu daya analisis terhadap suatu permasalahan [15]. Dimana jawaban yang telah didapatkan secara individu didiskusikan kembali pada tahap Pairing.

Pada tahap Pairing,guru memberikan kesempatan kepada siswa untuk merespon dan mendiskusikan kembali jawaban soal LKS yang didapat secara individu pada tahap Thinking. Pada tahap ini siswa juga diharapkan agar dapat saling membantu apabila anggota kelompoknya ada mengalami kesulitan dalam menyelesaikan soal LKS sehingga memungkinkan siswa yang kurang paham dapat menemukan pemahaman 
terhadap materi pelajaran melalui tukar pikiran atau diskusi dengan anggota kelompoknya dan dapat menyamakan jawaban atas pertanyaan soal LKS. Hal ini sesuai dengan penelitian Dian Anita Nugraha yang mengatakan bahwa adanya pembagian kelompok siswa dalam pembelajaran akan mendorong terjalinnya hubungan yang saling mendukung antar anggota kelompok. Siswa yang mengalami kesulitan dapat bertanya kepada teman dalam satu kelompoknya, sehingga diharapkan dapat meningkatkan kemampuan pemecahan masalah siswa dan hasil belajar yang diperoleh lebih maksimal [16].

Pada tahap terakhir yakni Sharing.Guru memberikan kesempatan kepada siswa untuk mempersentasekan hasil jawaban soal LKS yang telah masing-masing kelompok sepakati. Dimana guru akan menunjuk secara acak bagi kelompok yang akan mempersentasikan jawabannya di depan kelas.

Selain itu, model pembelajaran Think Pair Share dibantu dengan media Index Card Match. Dimana media Index Card Match adalah media kartu berpasangan yang sederhana dan menyenangkan. Siswa yang tidak memiliki keahlian dalam mengemukakan pemikirannya mau tidak mau akan bekerja dengan aktif dalam mencari pasangan dari kartu yang dimilikinya, dikarenakan sistem dari media pembelajaran ini adalah mencari pasangan dari kartu yang cocok atau sesuai antara pertanyaan dan jawaban yang dimiliki setiap siswa. Dimana siswa yang lebih dulu menemukan pasangan kartunya dipilih untuk mempersentasikan pertanyaan dan jawaban di depan kelas. Suasana belajar yang menyenangkan ini diharapkan mempengaruhi keberhasilan siswa dalam belajar dan mengembangkan kemampuannya serta diharapkan media ini dapat menambah pemahaman siswa terhadap materi. Hal ini sesuai dengan penelitian Dian Anita Nugraha yang menyatakan bahwa Index Card Match dapat meningkatkan pemahaman siswa tentang bahan pelajaran [17]. Beliau juga menyebutkan bahwa media tersebut mengandung sisi yang menarik, menyenangkan, dan mudah dilakukan [18].

Sedangkan pada kelas kontrol menggunakan pembelajaran konvensional, sehingga pengetahuan yang mereka dapatkan terbatas hanya pada apa yang dijelaskan dan yang telah didiskusikan sesama mereka saja. Bagi siswa yang memiliki keahlian dalam hal diskusi mungkin tidak terdapat masalah yang signifikan, namun bagi siswa yang mengalami masalah dalam hal diskusi akan berdampak terhadap partisipasinya dalam jalan nya diskusi. Maka diskusi tersebut hanya dikuasai oleh siswa yang memiliki keahlian diskusi saja, sehingga mengakibatkan pembelajaran condong ke arah satu sisi saja.

Dari pengolahan data analisa uji hipotesis, diperoleh nilai $\mathrm{t}_{\text {hitung }} 2,038$ dan nilai $t_{\text {tabel }}$ 2,00. Nilai $t_{\text {hitung }}>t_{\text {tabel. }}$ Hal ini menunjukan bahwa $\mathrm{H}_{\mathrm{o}}$ ditolak dan $\mathrm{H}_{\mathrm{a}}$ diterima. $\quad \mathrm{H}_{\mathrm{a}}$ diterima yaitu ada pengaruh penerapan model Think Pair Share dengan media Index Card Match terhadap hasil belajar kimia siswa pada materi hidrokarbon kelas $\mathrm{X}$ di SMA Negeri 2 Rumbiojaya dengan besar pengaruh $8,6 \%$.

Jadi dapat disimpulkan bahwa penerapan model pembelajaran Think Pair Share dengan media Index Card Match berpengaruh terhadap hasil belajar kimia siswa kelas X2 SMA Negeri 2 Rumbiojaya yaitu memberikan hasil belajar yang lebih baik pada kelas eksperimen dibandingkan dengan kelas X3 pada kelas kontrol yang hanya diimplementasikan dengan pembelajaran konvensional pada materi hidrokarbon.

\section{KESIMPULAN}

Berdasarkan hasil penelitian, dapat disimpulkan bahwa adanya pengaruh penerapan model Think Pair Share dengan media Index Card Match terhadap hasil belajar kimia siswa pada materi hidrokarbon kelas X di SMA Negeri 2 Rumbiojaya. Hal ini dapat dilihat dari nilai $t_{\text {hitung }}>t_{\text {tabel, }}$, dimana $t_{\text {hitung }}=2,038$ sedangkan nilai $t_{\text {tabel }}$ pada taraf signifikan $5 \%=2,00$. Rata-rata nilai posttest dari kelas eksperimen adalah 81,1 sedangkan 
rata-rata nilai posttest kelas kontrol adalah 77,5 dengan koefisien pengaruh $(\mathrm{Kp})$ sebesar $8,6 \%$.

\section{REFERENSI}

[1] Asmal may, Filsafat Pendidikan Islam (Pekanbaru: Suska Press, 2012), hal.5.

[2] Sitiatava Rizema Putra, Desain Belajar Mengajar Kreatif Berbasis SAINS (Jogjakarta: Diva Press, 2013), hal.16.

[3] Slameto, Belajar dan Faktot-faktor yang Mempengaruhi (Jakarta: Rineka Cipta, 2010), hal.2.

[4][7] Departemen Agama Islam RI, Alqur'an dan Terjemahannya (Jakarta: Agung Harapan, 2006), hal.701.

[5] Al Ghazali, Ihya Ulumuddin, hal.90.

[6] Aisah Ika Wardhani, Pengaruh Pembelajaran Kooperatif Model Think Pair Share (TPS) Menggunakan Strategi Peta Konsep dan Peta Pikiran Terhadap Prestasi Belajar Siswa Materi Ikatan Kimia Kelas XI SMA Negeri 1 Karanganyar Tahun Ajaran 2013/2014, Surakarta: Universitas Sebelas Maret, 2014, hal.37.

[8] Surayya. Pengaruh Model Pembelajaran Think Pair Share Terhadap Hasil Belajar IPA Ditinjau Dari Keterampilan Berpikir Kritis Siswa. Singaraja: Universitas Pendidikan Ganesha. 2014, hal.5.

[9][12][13] Muthiah Zuhara, Penerapan Model Pembelajaran Kooperatif Tipe Think Pair Share (TPS) Untuk Mengembangkan Karakter Siswa Pada Materi Larutan Elektrolit dan Nonelektrolit Di SMA 17 Agustus 1945, Surabaya: Universitas Negeri Surabaya, 2014, hal.63.

[10][11][16][17][18] Dian Anita Nugraha, Efektivitas Metode Pembelajaran Kooperatif Think Pair Share (TPS) yang Dilengkapi Media Kartu Berpasangan (Index Card Match) Terhadap Prestasi Belajar Siswa Pada Materi Ikatan Kimia Kelas X Semester Gasal SMA N 2 Karanganyar Tahun Pelajaran 2012/2013, Surakarta: Universitas Sebelas Maret, 2013, hal.176-179.
[14] Trianto, Mendesain Model Pembelajaran Inovatif-Progresif (Jakarta: Kencana Prenada Media Group, 2009), hal.222-223.

[15] Istirani, 58 Model Pembelajaran Inovatif, Medan: Media Persada, 2014, hal.68. 